\title{
Public health saves lives: sad lessons from COVID-19
}

\section{La santé publique sauve des vies : les tristes leçons de la COVID-19}

\author{
Louise Potvin ${ }^{1}$ \\ Published online: 1 June 2020 \\ (C) The Canadian Public Health Association 2020
}

In June 2019, the Journal published a special section on "Why Public Health Matters Today" following a call for submissions to the public health research and practice community. In their introductory comment (McLaren and Hancock 2019), the editors noted that numerous commentaries that presented convincing and appealing arguments to answer the question were received and published. In the same breath, they expressed worries about the dearth of submissions presenting empirical data on the estimated or observable benefits of public health. They called for increasing support for research in public health systems and in population health domains. At the moment of writing this editorial, the world holds its breath and stands still at the very beginning of a (probably) long-lasting relationship with a new virus, SARS-Cov-2, that causes severe viral pneumonia in vulnerable segments of the world population (mostly elderly people and people with compromised immune systems). In the absence of any population immunity, governments were faced with the cruel dilemma of preserving their economic growth or facing tens of thousands of deaths.

We all know that international comparisons about the devastating impact of COVID-19 are extremely difficult. Different demographic and economic structures, variations in testing strategies, in ways in which causes of deaths are identified and even in counting COVID-related deaths may very well explain much of the observed variations among countries and continents. It is still too early to draw firm conclusions but it appears that in countries where early and strong measures to stop the contagion were taken (massive testing, tracking, economic shutdowns), the epidemic curve remains

Louise Potvin

louise.potvin@umontreal.ca

1 Centre de recherche en santé publique, Université de Montréal et CIUSSS du Centre-Sud-de-l'Île-de-Montréal, Montreal, QC, Canada flatter and the mortality rate lower. For example, despite their geographical proximity to the point of origin of the pandemic, Vietnam, Taiwan and the Republic of Korea appear to have successfully limited the death toll of the epidemic.

Overall, at the moment of writing this editorial, Canada as a whole is doing fairly well. The federal and provincial governments have decreed and operated an early shutdown of the economy to facilitate physical distancing. These measures were coupled with strong social welfare programs to support those most affected by the side effects of the confinement requirements and the shutdown of the economy that ensued. The health of the population appears to be our governments' highest priority. They also appear to be listening to, and following, expert advice. At all levels, communications are frequent, transparent and from the highest possible source, the Prime Minister of Canada and Premiers in provinces. In most instances, government officials are flanked by their jurisdiction's directors of public health who, as expected from good doctors, regularly visit their sick patients, give progress reports, and provide counsels and prescriptions to heal faster.

To a large extent, the strategy is working. Social order is not threatened, provincial health-care systems appear to hold on even in provinces most affected, and the epidemic curves of cumulative cases and mortality are close to those of Germany, a country that is at the beginning of its recovering and reopening period. In addition, projections based on modelling of the progression of the disease transmission show that the strong public health strategy adopted and implemented in Canada saved tens of thousands of lives (Gouvernement du Canada 2020). Clearly, public health does save lives and on a grand scale. Not only does it save lives by constraining the contagion of a deadly disease, it also prevents the collapsing of health care facilities that continue to deal with regular emergencies. It is still too early to tell but it is very likely that excess mortality due to other causes will be higher in countries 
with high COVID-19 mortality, their health care systems having been clearly overwhelmed with the influx of severe cases.

However, the overall picture masks wide social, regional and health disparities, the most obvious being the extreme vulnerability of elderly people, for whom the lethality of the disease is nothing but dramatic. In this respect, the situation in Québec and in Ontario is most preoccupying. During his daily press conference on April 21, the Québec Premier François Legault admitted that there were in fact two different epidemic realities in the province. I believe that there are really three and that each show areas of strengths and vulnerability in our organizations of health care and public health. Further investigations of the ways in which these epidemiological realities were treated will certainly be warranted and will provide much needed knowledge on the functions of public health and on the organizational conditions to maximize its impact.

The first epidemic is taking place outside densely populated areas. These areas make up the great majority of our country's territory but are where only a minority of our fellow Canadians are living. In those places, the physical distancing required to slow the contagion appears to be easier, as shown by the low number of cases per population units and the shape of the curve that has been flattening for some days already, and that allowed Saskatchewan to start to implement its deconfinement strategy. The small number of cases allowed a competent and sufficient public health labour force to conduct the necessary epidemiological surveys and isolate potentially contaminated contacts. In this respect, the rapidity and efficacy with which the public health response was deployed in British Columbia to control the country's earliest outbreak is to be commended.

The second epidemic is taking place in large megalopolises wherein physical distancing is difficult to implement. In Toronto as in Montreal, the areas first hit were those where travellers were coming home from spring break and vacations abroad. Now the trend has changed course and it is community contagion that is the threat in low-income neighbourhoods where physical distancing is next to impossible. The crowding of social housing, the lack of access to credit or banking cards, the difficulty to communicate in either Canadian official language, the presence of the most vulnerable populations in shelters and in other collective housing arrangements, all increase the risk of contagion. For example, in Montreal, we have heard of cases of social housing units in which people still had to obtain and use small change in order to operate shared laundry equipment. Even in these difficult conditions, the contagion appears to be mostly under control, and despite the presence of more severe local outbreaks, public health organizations are able to conduct case-tracking surveys. Also, the number of severe cases is still well under the hospital capacity limits given the number of regular and ICU beds that were freed in advance of the outbreak. The impression is that despite the fact that the system was not completely ready, (insufficient numbers of) public health personnel are entirely dedicated to controlling the outbreak, and this at the expense of most other programs.

The third epidemic is the dramatic situation in nursing homes, which account for $80 \%$ of deaths in Québec and Ontario, mainly but not exclusively in Montreal and Toronto. Obviously, we are following the Québec situation more closely. It is clear there that the shortage and disengagement of caring personnel and the over-centralization of the health care system that resulted from the austerity budgets running from 2015 to 2018 and the 2015 health care reform are at the source of many of the problems that cascaded to produce the disaster currently unfolding in these institutions.

Until there is a vaccine that can be safely and efficiently administered on a grand scale to immunize $60 \%$ to $80 \%$ of the population, life as we have known it for the past decades will not resume. In addition, in weeks and months to come, we will mourn those whom our society has failed to protect from the infection and to cure from the disease. Our solace will be that as a public health community, we have warned in advance our leaders and fellow citizens that the world should not be taken for granted, and that public health is necessary to maintain our living standards and more basically, our lives. Even after our message was not acted upon, we have rolled up our sleeves and worked day and night to control and limit the impact of our collective carelessness. Canadians owe an immense thank you to the tireless public health professionals who are on the front line and whose work, although invisible, is saving thousands of lives.

The Canadian Journal of Public Health is eager to contribute to this effort and to offer a tribune to exchange results and practices in our collective effort to control SARS-Cov-2. To achieve this, we have created an ongoing open call for COVID-19-related contributions. Our Senior Editor, Dr. David Moore from the BC Centre of Excellence in HIV/ AIDS and an Associate Professor in the Department of Medicine at UBC, accepted to edit this collection. We commit to rapid screening and decisions to send manuscripts to peer review and rapid relaying of our decisions to authors. In addition, Springer will be making published COVID-related articles open access via Pub Med and the World Health Organization for the duration of the emergency.

Louise Potvin, $\mathrm{PhD}$

Editor-in-Chief

\section{Éditorial}

En juin 2019, la Revue publiait une rubrique spéciale, Pourquoi la santé publique aujourd'hui?, à la suite d'un appel d'articles lancé à la communauté des chercheurs et des praticiens de la santé publique. Dans leur commentaire 
d'introduction, les rédacteurs (McLaren and Hancock 2019) ont dit avoir reçu et publié de nombreux envois présentant des arguments convaincants et séduisants en réponse à cette question. En même temps, ils se sont dits inquiets du manque d'articles présentant des données empiriques sur les avantages estimés ou observables de la santé publique. Ils ont plaidé en faveur d'un soutien accru à la recherche sur les systèmes de santé publique et en santé des populations. Au moment d'écrire ces mots, le monde est immobilisé et retient son souffle aux tout premiers stades d'une relation (probablement) durable avec un nouveau virus, le SRASCov-2, qui cause une pneumonie virale sévère dans des segments vulnérables de la population mondiale (principalement les personnes âgées et celles dont le système immunitaire est affaibli). En l'absence de toute immunité de la population, les gouvernements ont été confrontés à un cruel dilemme : préserver leur croissance économique ou laisser des dizaines de milliers de personnes mourir.

Nous savons tous qu'il est extrêmement difficile de faire des comparaisons internationales des effets dévastateurs de la COVID-19. Les différentes structures démographiques et économiques et les variations dans les stratégies de dépistage et les façons de définir, ou même de compter, les décès liés à la COVID-19 pourraient très bien expliquer la plupart des écarts observés d'un pays et d'un continent à l'autre. Il est encore trop tôt pour tirer des conclusions fermes, mais il semble que dans les pays où des mesures précoces et vigoureuses ont été prises pour stopper la contagion (dépistage de masse, traçage, fermeture de l'économie), la courbe épidémique reste aplatie, et le taux de mortalité est plus bas. À titre d'exemple, malgré leur proximité géographique avec le point d'origine de la pandémie, le Vietnam, Taïwan et la République de Corée semblent avoir réussi à limiter le nombre de victimes de l'épidémie.

En général, au moment d'écrire ces lignes, le Canada dans son ensemble s'en tire passablement bien. Le gouvernement fédéral et ceux des provinces ont décrété et exécuté la fermeture rapide de l'économie pour faciliter la distanciation physique. Cette mesure s'est accompagnée de solides programmes de sécurité sociale pour aider les personnes les plus touchées par les effets secondaires du confinement nécessaire et de la fermeture de l'économie qui a suivi. La santé de la population semble être la priorité absolue pour nos gouvernements. Ceux-ci semblent aussi écouter, et suivre, les conseils des experts. À tous les paliers, les communications sont fréquentes, transparentes et proviennent de la source la plus élevée, soit le premier ministre du Canada et les premiers ministres des provinces. Dans la plupart des cas, les politiciens sont encadrés par leurs directeurs ou directrices de la santé publique, qui tels de bons médecins, visitent périodiquement leurs patients malades, donnent des rapports de suivi et offrent des conseils et des ordonnances pour qu'ils guérissent plus vite.
Dans une large mesure, la stratégie fonctionne. L'ordre social n'est pas menacé, les systèmes de soins de santé provinciaux semblent tenir le coup même dans les provinces les plus touchées, et les courbes épidémiques des cas et des décès cumulatifs sont proches de celles de l'Allemagne, un pays qui vient d'entamer sa période de rétablissement et de réouverture. En outre, les extrapolations fondées sur les modèles d'évolution de la transmission de la maladie montrent que la vigoureuse stratégie de santé publique adoptée et appliquée au Canada a sauvé des dizaines de milliers de vies (Gouvernement du Canada 2020). Il est clair que la santé publique sauve des vies, et à grande échelle. Non seulement limite-t-elle la contagion d'une maladie mortelle, mais elle prévient l'effondrement des établissements de soins de santé, qui composent encore avec les urgences habituelles. Il est encore trop tôt pour le savoir, mais il est très probable que la surmortalité due aux autres causes sera plus élevée dans les pays où la COVID-19 a fait beaucoup de morts, leurs systèmes de soins de santé ayant clairement été submergés par l'afflux de cas graves.

Néanmoins, ce portrait général masque d'importantes disparités sociales, régionales et de l'état de santé, la plus évidente étant l'extrême vulnérabilité des personnes âgées, chez qui la létalité de la maladie est rien de moins que catastrophique. À cet égard, la situation au Québec et en Ontario est hautement préoccupante. Durant son point de presse quotidien du 21 avril, le premier ministre François Legault a admis que l'épidémie avait deux visages au Québec. Je crois qu'en fait elle en a trois, et que chacun de ces visages montre les forces et les vulnérabilités de nos systèmes de soins de santé et de santé publique. Il sera sûrement justifié d'enquêter plus avant sur la façon dont nous avons composé avec ces réalités épidémiologiques, et cela nous fournira des connaissances très nécessaires sur les fonctions de la santé publique et sur les conditions organisationnelles qui en optimisent l'impact.

La première épidémie se trouve hors des zones densément peuplées. Ces zones constituent la grande majorité du territoire de notre pays, mais seule une minorité de nos concitoyens y habitent. À ces endroits, la distanciation physique nécessaire pour ralentir la contagion semble plus facile, comme en témoigne le faible nombre de cas par habitant et la forme de la courbe, qui s'aplatit depuis quelques jours déjà, ce qui a permis à la Saskatchewan de commencer à appliquer sa stratégie de déconfinement. Le petit nombre de cas a permis aux personnels de la santé publique, compétents et en nombre suffisant, de procéder aux enquêtes épidémiologiques nécessaires et d'isoler les contacts potentiellement contaminés. À ce propos, la rapidité et l'efficacité avec laquelle la santé publique a déployé sa riposte en Colombie-Britannique pour contrôler le tout premier foyer de l'éclosion au pays est digne de mention.

La deuxième épidémie se trouve dans les grandes mégalopoles où la distanciation physique est difficile à mettre 
en œuvre. À Toronto comme à Montréal, les zones touchées en premier ont été celles où des voyageurs sont retournés du congé scolaire du printemps et de vacances à l'étranger. À présent, la tendance a changé de cap, et c'est la contagion communautaire qui représente la plus grande menace, dans les quartiers à faible revenu où la distanciation physique est presque impossible. L'encombrement des logements sociaux, le manque d'accès au crédit ou aux cartes bancaires, la difficulté de communiquer dans l'une ou l'autre des langues officielles, la présence des populations les plus vulnérables dans les refuges et autres logements collectifs, tout cela fait augmenter le risque de contagion. À Montréal par exemple, nous avons entendu parler d'unités de logement social où les gens doivent encore se procurer et utiliser des pièces de monnaie pour utiliser les laveuses-sécheuses communes. Même dans ces conditions difficiles, la contagion semble être en grande partie sous contrôle, et malgré la présence de foyers locaux plus graves, les organismes de santé publique sont en mesure de mener des enquêtes de suivi des cas. Le nombre de cas graves est aussi bien en deçà du seuil de capacité des hôpitaux, vu le nombre de lits ordinaires et de soins intensifs qui ont été libérés en prévision de l'éclosion. On a l'impression que bien que le système n'ait pas été tout à fait prêt, les personnels de santé publique (en nombre insuffisant) sont entièrement au service de la lutte contre l'éclosion, même aux dépens de la plupart des autres programmes.

La troisième épidémie est la situation dramatique dans les centres d'hébergement et de soins de longue durée, où l'on recense $80 \%$ des décès au Québec et en Ontario, principalement mais non exclusivement à Montréal et à Toronto. De toute évidence, nous suivons de plus près la situation au Québec. Il est clair, dans la province, que la pénurie de personnel soignant, le désengagement du personnel et la centralisation à outrance du système de soins de santé qui a résulté des budgets d'austérité de 2015 à 2018 et de la réforme des soins de santé de 2015 sont à la source d'un bon nombre de problèmes qui se sont répercutés en cascade pour produire la catastrophe actuelle dans ces centres.

Jusqu'à ce qu'il y ait un vaccin qui puisse être administré efficacement, sans danger et à grande échelle pour immuniser de $60 \%$ à $80 \%$ de la population, la vie telle que nous l'avons connue au cours des décennies antérieures ne reprendra pas son cours. De plus, durant les semaines et les mois à venir, nous pleurerons les victimes que notre société n'aura pas su protéger contre l'infection ni guérir de la maladie. Notre seul réconfort sera de savoir que la communauté de la santé publique aura prévenu à l'avance nos dirigeants et nos concitoyens qu'il ne faut pas prendre le monde pour acquis, et que la santé publique est nécessaire au maintien de notre niveau de vie et, plus fondamentalement, à notre survie. Même si notre message n'a pas été entendu, nous avons relevé nos manches et travaillé jour et nuit à contrôler et à limiter les dégâts de notre insouciance collective. Les Canadiens doivent un immense merci aux infatigables professionnels de la santé publique présents aux premières lignes, dont le travail, bien qu'invisible, sauve des milliers de vies.

La Revue canadienne de santé publique souhaite vivement contribuer à cet effort en offrant une tribune où partager les résultats et les pratiques de notre lutte collective contre le SRAS-Cov-2. Pour cela, nous lançons un appel ouvert et continu d'articles liés à la COVID-19. Notre rédacteur scientifique adjoint, $\mathrm{D}^{\mathrm{r}}$ David Moore du Centre d'excellence pour le VIH/sida de la Colombie-Britannique, qui est aussi professeur agrégé à la Faculté de médecine de l'Université de la Colombie-Britannique, a accepté de diriger cette collection. Nous nous engageons à faire preuve de rapidité dans le tri des manuscrits et la décision de les envoyer ou non pour évaluation par les pairs, ainsi que dans la communication de nos décisions aux auteurs. En outre, tant que durera l'urgence, Springer offrira en accès libre les articles publiés sur la COVID via PubMed et l'Organisation mondiale de la santé.

Louise Potvin, Ph.D.

Rédactrice en chef

\section{References/Références bibliographiques}

Gouvernement du Canada (2020). La COVID-19 au Canada: des données et une modélisation qui éclairent les mesures de santé publique. Retrieved from: https://www.canada.ca/fr/santepublique/services/publications/maladies-affections/covid-19donnees-modelisation-eclairent-mesures-sante-publique.html\#a2. Accessed 26 May 2020.

McLaren, L., \& Hancock, T. (2019). Public health matters - but we need to make the case. Canadian Journal of Public Health, 110, 264 269.

Publisher's note Springer Nature remains neutral with regard to jurisdictional claims in published maps and institutional affiliations. 